\title{
A floristic survey of Fair Isle II: new and notable records and the status of Euphrasia
}

\author{
Nick J. Riddiford ${ }^{1 *}$; Camila V. Quinteros Peñafiel ${ }^{2}$; Chris Metherell ${ }^{3}$; C. Claudia \\ Ferguson-Smyth ${ }^{4}$; Alex D. Twyford ${ }^{5}$ \\ ${ }^{1}$ Fair Isle, Scotland; ${ }^{2}$ Punta Arenas, Chile; ${ }^{3}$ Morpeth, England; ${ }^{4}$ Broughton, Scotland; \\ ${ }^{5}$ Edinburgh, Scotland
}

*Corresponding author: Nick J. Riddiford: taib.nick@gmail.com

This pdf constitutes the Version of Record published on $30^{\text {th }}$ June 2020

\begin{abstract}
Fair Isle is a small island of 768 hectares located half way between Orkney and Shetland. In the previous publication of Quinteros Peñafiel et al. (2017), we provided a complete flora for the island. This note updates the status of the Fair Isle flora subsequent to the survey by including corrections, new finds and other notable records.
\end{abstract}

Key words Shetland; casual introductions; island biodiversity; taxonomic complexity; eyebright.

\section{Highlights}

There was an unexpected number of additions to the Fair Isle list, particularly, in 2018. These were largely the secondary outcome of supplementary birdseed provision at a feeding station run by the Fair Isle Bird Observatory and accidental introductions of horticultural derivation. The means of arrival for other species are less clear but include two potential invasives, Chamaenerion angustifolium and Jacobaea vulgaris. Fair Isle's stormy seas provide a more natural route to the isle for maritime plants, and it was gratifying to find Honckenya peploides after an absence of 27 years. Human helping hands, however, have allowed it to establish inside a fenced enclosure erected some years before to protect Mertensia maritima (colonised 1992) from sheep. Another species which had "gone missing" for a number of years, the diminutive Myosotis discolor, was discovered at two sites in 2019. Recent renewed interest in Fair Isle botany has led to more detailed research into dandelion (Taraxacum) taxa and a complete review of eyebright (Euphrasia) taxa. Nomenclature follows New Flora of the British Isles, $4^{\text {th }}$ ed. (Stace, 2019)

\section{Corrections}

Taraxacum lapponicum (Kihlman) Kihlman ex Handel-Mazzetti, 1907: cited in Quinteros Peñafiel et al. (2017) has been reassessed as Taraxacum faeroense agg. (Dahlst.) Dahlst. [ $T$. lapponicum is a North American species not recognised in the British and Irish flora].

Fair Isle list amendment: remove Taraxacum lapponicum (misinterpretation). 
Ballota nigra L.: cited in Quinteros Peñafiel et al., (2017) has been re-identified as Stachys sy/vatica L.

Fair Isle list amendment: remove Ballota nigra (misidentification) and replace with Stachys sylvatica (re-determination).

\section{Additions}

Dryopteris filix-mas (L.) Schott: cluster in hole sunk into bank of stream, Funniequoy Gully (HZ 217 719), 16 August 2018, det. Hazel Metherell

Fair Isle status: first confirmed Fair Isle record; rare overlooked native or colonist.

Humulus lupulus L.: rampant, garden border, Lower Stoneybrek (HZ 205 709), 7 September 2018, det. Glen A. Tyler

Fair Isle status: first Fair Isle record, present undetermined for several years; casual introduction.

Dysphania ambrosioides (L.) Mosyakin \& Clemants: one robust plant in unplanted peat-filled pot, polytunnel, Lower Stoneybrek (HZ 205 709), 27 August 2018, Pat Thomson, det. N. J. Riddiford

Fair Isle status: first Fair Isle record; casual, provenance unknown (probably with imported horticultural materials or produce); did not persist into 2019.

Chenopodium polyspermum L.: one flowering plant, small patch cleared of vegetation, Lower Stoneybrek (HZ 205 709), 21 August 2018, det. Pat Thomson \& N. J. Riddiford

Fair Isle status: first Fair Isle record; casual, provenance unknown; did not persist into 2019.

Atriplex praecox Hülph.: plentiful, band of finer shingle, seaward end of beach, Muckle Uri Geo (HZ 198 697), 17 June 2018, det. Tony Vials, verified (from specimen) Dr J. R. Akeroyd (Fig. 1)

Fair Isle status: first Fair Isle record; recent colonist or overlooked native.

Atriplex glabriuscula x A.longipes $=$ A $x$ taschereaui Stace: in Atriplex "swarm" across shingle beach, Muckle Uri Geo beach (HZ 198 697), 8 August 2018, leg. N. J. Riddiford, det. (from specimen) Dr J. R. Akeroyd

Fair Isle status: first Fair Isle record; probably overlooked native.

Erucastrum gallicum (Willd.) O. E. Schulz: two flowering plants, below winter bird feeding station, Bird Observatory at Mavers Cup (HZ 222 723), 25 July 2018, det. N. J. Riddiford

Fair Isle status: first Fair Isle record; casual introduction; did not persist into 2019.

Sedum telephium L.: two in flower, Houll Cuppas (HZ 205 706), 18 September 2017, N. J. Riddiford

Fair Isle status: first "non-garden" Fair Isle record; self-seeded escape (only garden site $400 \mathrm{~m}$ south); did not persist into 2018. 


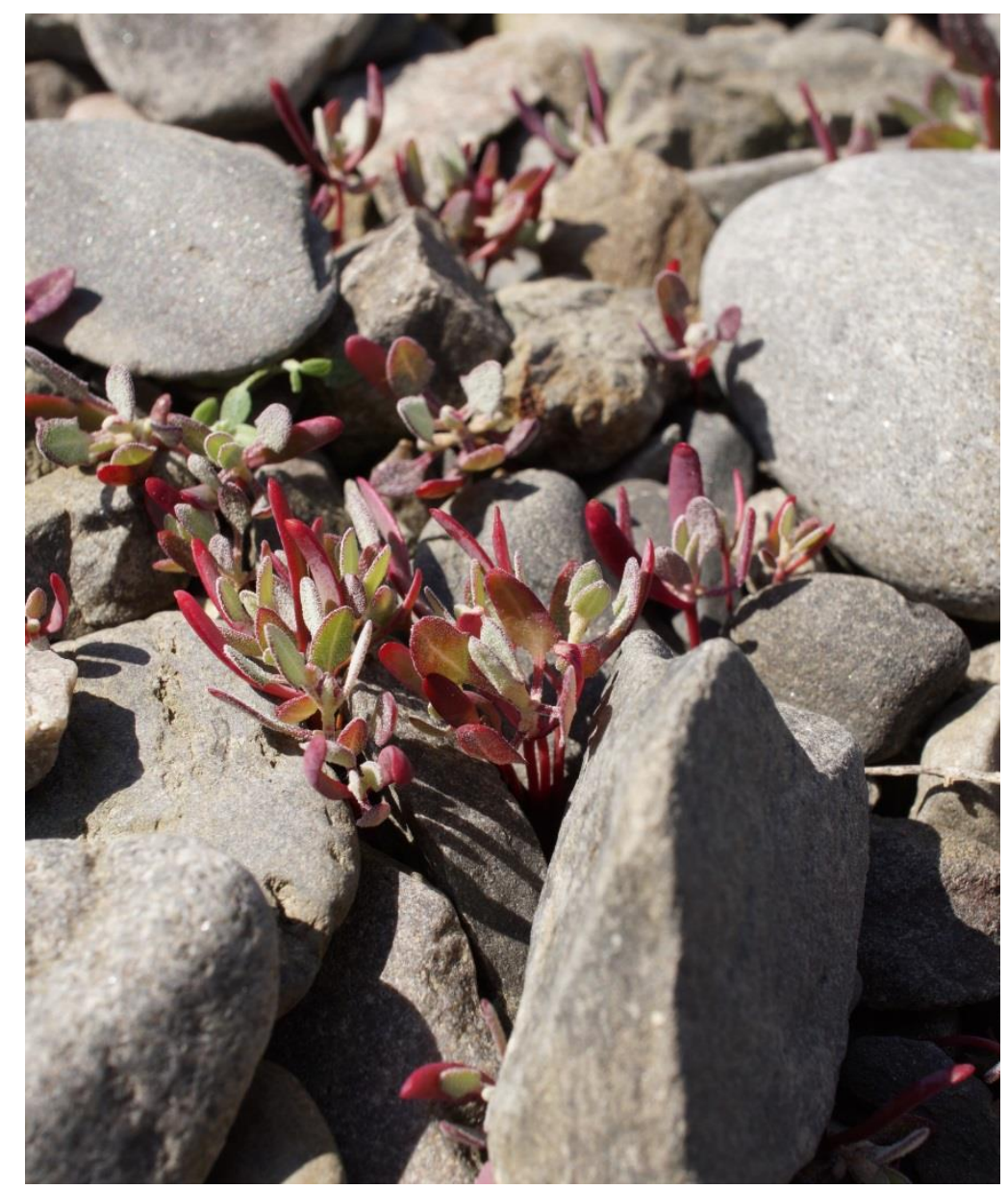

Figure 1. Atriplex praecox on Fair Isle, June 2018

Chamaenerion angustifolium (L.) Holub.: 10 plants, one in flower, disturbed ground behind outbuilding, Bird Observatory at Mavers Cup (HZ 222 723), 16 August 2018, det. Max Brown

Fair Isle status: first Fair Isle record; recent colonist, probably within the last two to three years.

Linum perenne L.: one in flower \& one seed pod, small prepared patch sowed with packet of "wildflower seed" from conservation body, Brecks (HZ 2078 7022), 7 August 2018, det. N. J. Riddiford.

Fair Isle status: first Fair Isle record; casual introduction; did not persist into 2019.

Cichorium intybus L.: one in flower, small prepared patch sowed with packet of "wildflower seed" from conservation body, Brecks (HZ 2078 7022), 23 August 2018, det. N. J. Riddiford

Fair Isle status: first Fair Isle record; casual introduction; did not persist into 2019.

Jacobaea vulgaris L.: one in flower \& one non-flowering rosette, gravelly bank adjacent to building, Bird Observatory at Mavers Cup (HZ 2221 7231), 25 July 2018, det. N. J. Riddiford

Fair Isle status: first Fair Isle record; recent colonist, probably within the last five years. 
Taraxacum aequilobium Dahlst.: small enclosed garden, primary school HZ2078 7093 \& HZ2078 7095, 25 May 2017 - leg. C. C. Ferguson-Smyth, det. A. J. Richards Fair Isle status: first Fair Isle record, probably overlooked established colonist.

Taraxacum cophocentrum Dahlst.: rough ground, coastguard station HZ203 707, 29 May on rough disturbed ground, fire station HZ2078 7098, 30 May $2017-$ leg. C. C. Ferguson-Smyth, det. A. J. Richards

Fair Isle status: first Fair Isle record, probably overlooked native.

Taraxacum fasciatum Dahlst.: rough ground, coastguard station HZ203 707, 29 May \& disturbed ground, loc. cit., HZ2034 7071, 30 May 2017 - leg. C. C. FergusonSmyth, det. A. J. Richards

Fair Isle status: first Fair Isle record, probably overlooked native.

Taraxacum ochrochlorum Haglund ex Rail.: within walled garden, North Shirva (Nurse's house) HZ203 707, 29 May 2017 - leg. C. C. Ferguson-Smyth, det. A. J. Richards

Fair Isle status: first Fair Isle record, probably overlooked established colonist.

Taraxacum sahlinianum Dudman \& Richards: ruderal, post office HZ2045 7085, 29 May \& rough disturbed ground, fire station HZ2078 7098, 30 May $2017-$ leg. C. C. Ferguson-Smyth, det. A. J. Richards

Fair Isle status: first Fair Isle record, probably overlooked native.

Taraxacum valens Marklund: deep grass, George Waterston Museum HZ2023 7026, 28 May 2017; within walled garden, North Shirva (Nurse's house) HZ203 707, 29 May 2017; rough disturbed ground, fire station HZ2078 7098, 30 May $2017-$ leg. C. C. Ferguson-Smyth, det. A. J. Richards

Fair Isle status: first Fair Isle record, established or recent colonist.

Gaudinia fragilis (L.) P. Beauv.: one, below winter bird feeding station, Bird Observatory at Mavers Cup (HZ 222 723), 16 August 2018, det. N. J. Riddiford Fair Isle status: first Fair Isle record; casual introduction; did not persist into 2019.

Anisantha sterilis (L.) Nevski: two plants, below winter bird feeding station, Bird Observatory at Mavers Cup (HZ 222 723), 25 July 2018, det. N. J. Riddiford Fair Isle status: first Fair Isle record; casual introduction; did not persist into 2019.

\section{Other notable records}

Pteridium aquilinum subsp. aquilinum (L.) Kuhn

Fair Isle status: Fair Isle plants confirmed as this subspecies, 16 August 2018, det. Hazel \& Chris Metherell.

Ranunculus repens var. pleniflorus Fernald: one in flower, North Light (HZ 22 74), June 2017, Rebecca Watson, det. Rafaël Govaerts (RBS Kew) from photos. 
Fair Isle status: first record of this var.; the typical form is common and widespread ( $83 \%$ of monads, $n=18$ ) across the island.

Atriplex patula L.: two plants of a narrow-leaved form, recently disturbed untended garden, Bird Observatory at Mavers Cup (HZ 22217 72316), 27 August 2018, N. J. Riddiford

Fair Isle status: previously recorded at same site, 1999, det. Dr J. R. Akeroyd.

Chenopodium murale (L.): row of eight, in flower, edge of vegetable plot, Brecks (HZ 207 702), 23 August 2018, N. J. Riddiford

Fair Isle status: second record, previously August 2010; casual, probably an incidental component of imported vegetable seed packet; did not persist into 2019.

Honckenya peploides (L.) Ehrh.: one plant, shingle beach, Muckle Uri Geo (HZ 198 697), 17 June 2018, N. J. Riddiford

Fair Isle status: first record since 1981; natural re-colonisation after previous loss; plant still present and more robust 2019 with second plant $50 \mathrm{~cm}$ away.

Diplotaxis tenuifolia (L.) DC.: one plant, weed of vegetable garden, Brecks (HZ 207 702), 23 August 2018, N. J. Riddiford

Fair Isle status: second location, casual, possibly imported with "garden salad" seeds; two substantial clumps at first location, Upper Leogh 2013, still persisting strongly into 2019.

Lysimachia arvensis (L.): substantial plant, in flower, Lower Stoneybrek garden HZ 2054 7092, 16 July 2017, Pat \& Neil Thomson

Fair Isle status: first record for at least 70 years; casual introduction, did not persist into 2018.

Rosa canina L.: substantial shrub, in flower, halfway down cliff, Shieldi Geo (HZ 212 708), 15 July 2018, Pat \& Neil Thomson, verified from sample, 28 August 2018, leg. (by abseil) N. Thomson, det. N. J. Riddiford

Fair Isle status: last reported 1917; overlooked for 101 years!

Trifolium repens L.: tufts of leaves sprouting from flowers (leaf proliferation caused by Candidatus Phytoplasma trifolii bacterium), Houll Cuppas (HZ 205 706), 8 September 2018, det. N. J. Riddiford

Fair Isle status: not previously recorded, still present into 2019.

Trifolium pratense L.: one plant in flower, potato rig, Busta (HZ 2069 7012), 23 August 2018, N. J. Riddiford

Fair Isle status: intermittent casual, seemingly incapable of persisting; possibly present in seed bank \& requiring soil disturbance - e.g. ploughing for arable - to reactivate.

Heracleum sphondylium L.: one in flower, alongside parked car, Upper Stoneybrek, (HZ 20641 70978), 11 July 2017, still present, flowering, August 2018, N. J. Riddiford 
Fair Isle status: first record since the 1960s; casual, probably accidentally imported as seed with agricultural goods or on the car; plant removed by new croft tenant in 2019.

Myosotis discolor Pers.: group of 50, dry shallow soil, Schoolton (HZ 204 704), 12 June 2019, N. J. Riddiford; group of 10, raised hump of acid grassland, Taing (HZ 20861 70803), 10 July 2019, N. J. Riddiford

Fair Isle status: first record since the 1990s; cited as $N^{*}$ (Native, extinct) in Quinteros Peñafie/ et al. (2017); Fair Isle plants best placed under subspecies dubia (Arrondeau) Blais (see Scott \& Palmer, 1987).

Zostera marina L.: substantial strand, unattached, South Haven beach (HZ 224 724), 30 July 2018, N. J. Riddiford

Fair Isle status: third Fair Isle record; previously 2017 \& 1982; all drift material, nearest known colony Orkney.

The following additional species, with Fair Isle status in parentheses, were recorded as casual introductions via 1) seed spillage at a wild bird feeding station (HZ 222 723) or 2) sowing of a "wildflower" seed packet (HZ 2078 7022) in 2018

1. Chenopodium album L. (occasional); Brassica rapa L. oleifera DC (occasional); Avena sativa L. (occasional); Phalaris canariensis L. (fifth record); Bromus hordeaceus $\mathrm{L}$. (third record); Triticum aestivum L. (occasional)

2. Trifolium pratense L. (a pale rose-coloured variety); Myosotis arvensis (L.) Hill (more robust habit than native plants); Achillea millefolium L. (much more robust habit than native plants)

None persisted into 2019 at either locality.

\section{A species list of Euphrasia}

Work has begun to decipher the range of Euphrasia taxa across the island.

Euphrasia taxa are renowned for being taxonomically complex and therefore difficult to identify, with Fair Isle plants being particularly problematic for three reasons. First, plants are often extremely dwarfed by the environment and are also lateflowering, thus falling outside the phenotypic range typical of species. Second, habitat heterogeneity and extensive roadside disturbance create the conditions for complex genetic mixes that would rarely be encountered in more discrete environments. Third, the small geographic scale and relatively small population sizes of some species means mean that unusual morphotypes can become abundant. The latter point is particularly notable on Fair Isle, with our field observations revealing plants with unusual dark-pigmentation of vegetative parts, as well as plants with fused floral parts (see Fig. 2). These represent odd morphological varieties not known from other localities. Collectors should also be aware that extensive sheepgrazing often causes damage and induces atypical branching patterns. Our species identifications proposed below follow our current understanding of Euphrasia taxonomy outlined in the BSBI Handbook on Euphrasia (Metherell \& Rumsey, 2018).

Further morphological studies are required to clarify the identity of the complex coastal taxa, including complex genetic mixes. We also hope that the use of genetic approaches (Wang et al., 2018) and common garden experiments (Twyford et al., 2019) will help clarify the distinctiveness of Euphrasia species on Fair Isle. We have 
identified putative hybrids following the definitions in the Euphrasia handbook (Metherell \& Rumsey, 2018), but with the knowledge that many of these plants may not actually be of hybrid origin. There are some very good examples of true hybridity on Fair Isle but in other cases, plants may show unusual variation found within a species, or be dwarfed forms stunted by local conditions. Alternatively, they may be more complex genetic mixes such as backcrosses.

Our current taxon list, based on field studies and herbarium work, includes eight species and eight putative hybrids. This includes a new record for E. heslopharrisonii and six additional genetic mixes.

Euphrasia arctica Lange ex Rostrup: widespread in grassland habitats, particularly along roadside verges in the south of the island. The disturbed nature of roadsides with ample opportunities for genetic mixing greatly affects the morphology of many $E$. arctica plants on Fair Isle. Some individuals appear to have some characters of $E$. nemorosa (Pers.) Wallr., although this species appears not to be present on the isle, while plants related to $E$. arctica with small corollas and apically directed basal teeth are currently of unknown identity.

Euphrasia confusa Pugsley: localised in grassy verges where it mixes with other Euphrasia taxa. The overall status of this species is uncertain as morphologically distinct individuals are scarce and as the $E$. confusa character of dense basalbranching is likely to be common in other late-establishing island Euphrasia species.

Euphrasia foulaensis F. Towns. ex Wettst.: extremely abundant in coastal turf. Typical plants are diminutive, without long hairs, and are very small flowered (sometimes cleistogamous). Plants with $E$. foulaensis characters but larger and more richly branched are found in sheltered habitats, such as by the roadside near the north lighthouse. These key to E. confusa x foulaensis in Metherell \& Rumsey (2018) but may prove to be vigorous $E$. foulaensis individuals.

Euphrasia heslop-harrisonii Pugsley: a problematic species in general, and also problematic on Fair Isle. Patchy distribution in coastal grassland, with further work required to determine its status and distribution.

Euphrasia marshallii Pugsley: widespread in coastal turf where it frequently cooccurs and mixes with $E$. foulaensis. Fair Isle provides an excellent opportunity to see large stands of this nationally rare species.

Euphrasia micrantha Rchb.: abundant in heather moorland. Fair Isle plants frequently have dark magenta corollas rather than the typical purple of other populations of $E$. micrantha, and thus may represent a local variety.

Euphrasia ostenfeldii (Pugsley) Yeo: scarce on the exposed short grassland of Ward Hill.

Euphrasia scottica Wettst.: uncommon, though locally abundant in the wet flush near the airstrip. Note that most slender white-flowered Euphrasia on Fair Isle are the white-flowered form of E. micrantha rather than E. scottica. 
Euphrasia arctica x heslop-harrisonir: identified from a single collection (HZ 2042 7017) of E. heslop-harrisonii flowering from a high node and with large corollas.

Euphrasia arctica $\mathrm{x}$ nemorosa: present along a roadside in the south of the island. Plants present a range of morphological variation including that close to $E$. nemorosa.

Euphrasia confusa $\mathrm{x}$ foulaensis. found in sheltered grassland proximal to the coast. In addition to highly branched $E$. foulaensis (described above), some plants demonstrate narrow corollas, with subacute leaf apices, leaf teeth longer than wide, and some short capsules, all typical of $E$. confusa.

Euphrasia foulaensis $\mathrm{x}$ marshallii: occasional, though likely to be overlooked in the frequent areas of sympatry between these two common coastal species.

Euphrasia foulaensis $\mathrm{x}$ micrantha: found in a complex roadside swarm of mixed affinity in the north of the island.

Euphrasia foulaensis x ostenfeldii: adjacent to the E. ostenfeldii population on Ward Hill. Similar to $E$. ostenfeldii, but almost glabrous and with long capsules.

Euphrasia heslop-harrisonii x marshallii: found on Ward Hill.

Euphrasia micrantha x scottica: locally common, including near the Airstrip and Burn of Wirvie.

\section{Concluding Remarks}

The survey of 2016 (Quinteros Peñafiel et al., 2017) built on the pioneering work of renowned Shetland botanist, Walter Scott - sadly deceased in 2018 - and gave a modern assessment of the flora. The current update outlines gains since then. They reveal some of the means of arrival on the isle and the failure or otherwise of colonisers to establish. Despite a history of botanical interest and the small size of Fair Isle, recent finds also demonstrate how easy it is to overlook diminutive species. Interest in the island's vascular plants remains high and benefits from visiting botanists, observant members of the Fair Isle population and a resident observer (the lead author) who has provided continuity from 1981 to the present, allowing some reflection on short-term as well as long-term change. Many of the recent arrivals are clearly generated by indirect or direct human activities and relate to plants which do not persist. With climate-driven environmental change much in people's minds, Fair Isle is in a strong position to monitor the impacts; which include prospects of gains - e.g. plants establishing which previously were not able to adapt to local conditions - and of losses.

In light of changes since 2016, the Fair Isle vascular flora list stands at 260 UK native species (plus $71 \mathrm{UK}$ aliens). The total number of species known to be present in 2019 comprised 235 UK natives (and 42 UK aliens). 


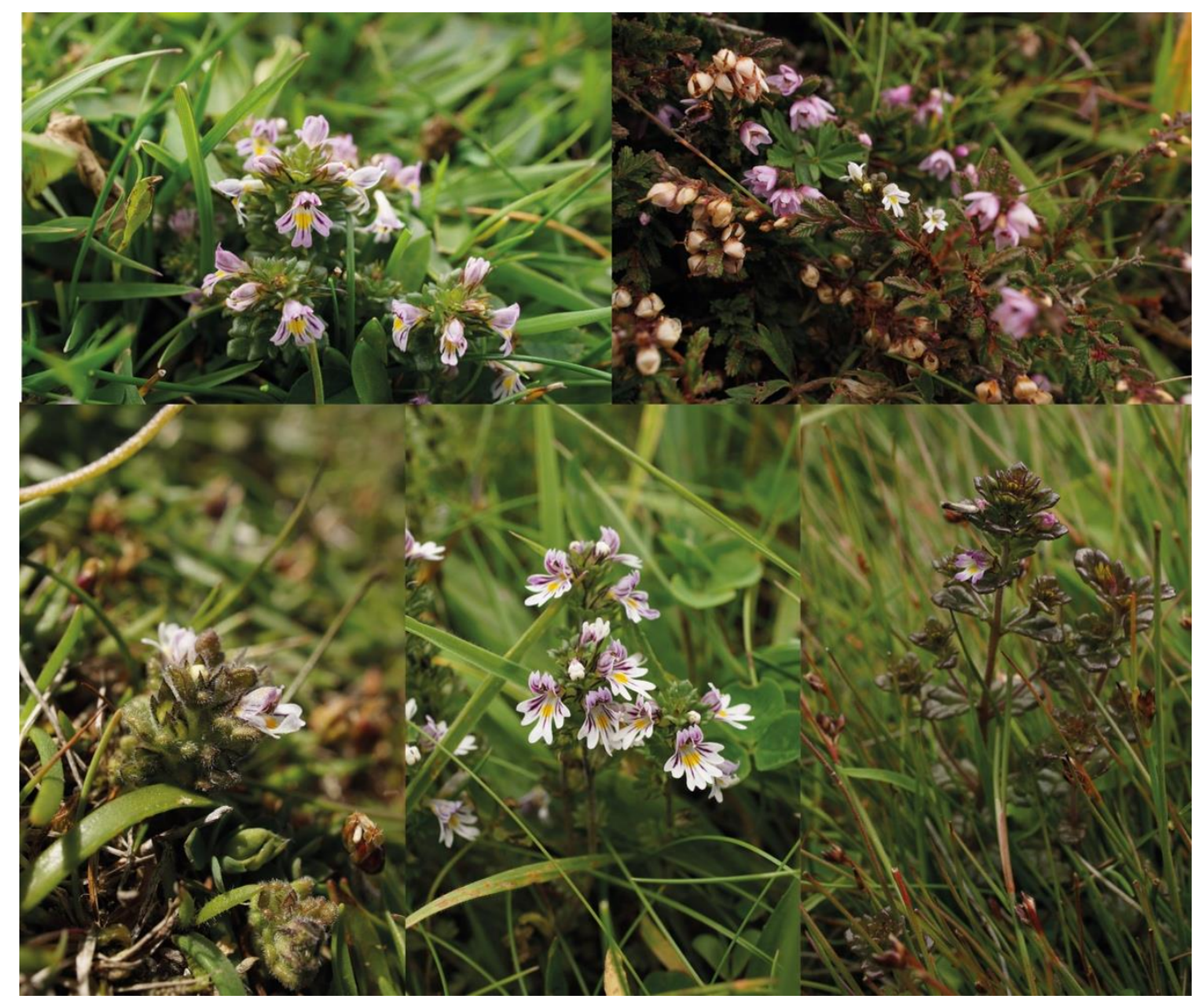

Figure 2. Euphrasia diversity on Fair Isle. Euphrasia foulaensis at North light (top left), white form of Euphrasia micrantha at Byerwall (top right), Euphrasia marshallii at South light (bottom left), Euphrasia arctica x confusa at Upper Stonybreck (bottom middle), Euphrasia micrantha hybrid at Homisdale (bottom right). Photos: Tony Vials.

\section{Acknowledgements}

We are grateful to Dr John Akeroyd, Dr Ian Denholm, Hazel Metherell and A. J. Richards for expert verifications; Max Brown, Hannes Becher, Pat and Neil Thomson, Glen Tyler and Tony Vials for field assistance and provision of records; Fair Isle Bird Observatory Trust for logistical support; and the people of Fair Isle, along with the National Trust for Scotland, for access to sites.

\section{References}

Metherell, C. \& Rumsey, F. J. 2018. Eyebrights (Euphrasia) of the UK and Ireland. BSBI Handbook 18, Bristol: Botanical Society of Britain and Ireland.

Quinteros Peñafiel, C. V., Riddiford, N. J. \& Twyford, A. D. 2017. A floristic survey of Fair Isle. New Journal of Botany 7 (2-3): 101-111. https://doi.org/10.1080/20423489.2017.1393191

Scott, W. \& Palmer, R. C. 1987. The Flowering Plants and Ferns of the Shetland Islands. Lerwick: The Shetland Times.

Stace, C. A. 2019. New Flora of the British Isles, 4th ed. Middlewood Green, Suffolk: C \& M Floristics.

Brown, M. R., Frachon, N., Wong, E. L. Y., Metherell, C. \& Twyford, A. D. 2020. Life history evolution, species differences, and phenotypic plasticity in hemiparasitic 
eyebrights (Euphrasia). American Journal of Botany 107(3): 456- 465. https://doi.org/10.1002/ajb2.1445

Wang, X., Gussarova, G., Ruhsam, M., de Vere, N., Metherell, C., Hollingsworth, P.M. \& Twyford, A. D. 2018. DNA barcoding a taxonomically complex hemiparasitic genus reveals deep divergence between ploidy levels but lack of species-level resolution. AOB PLANTS 10(3). https://doi.org/10.1093/aobpla/ply026

Copyright retained by author(s). Published by BSBI under the terms of the Creative Commons Attribution 4.0 International Public License.

ISSN: $2632-4970$

https://doi.org/10.33928/bib.2020.02.144 